A N N A L E S

UNIVER S T ATIS M A R A E C URIE-SKŁODOW K A

LUBLIN - POLONIA

VOL. XXXII, 3

SECTIO J

2019

Uniwersytet Jagielloński. Wydział Filozoficzny

BARBARA JAMROZOWICZ

ORCID: 0000-0001-8744-1631

barbara.jamrozowicz@uj.edu.pl

\title{
O podręcznikowej (homo)seksualności w kontekście polskim - od paniki moralnej do wojny kulturowej
}

On Textbook (Homo)Sexuality in the Polish Context - from Moral Panic to Cultural War

\section{STRESZCZENIE}

W niniejszym opracowaniu nowy sposób regulowania intymności oraz wojna kulturowa stały się kontekstem analiz dla obecnej w podręcznikach do zajęć z zakresu wychowania do życia w rodzinie homoseksualności. Na przestrzeni ostatnich kilkunastu lat kwestie dotyczące homoseksualizmu występowały w tej grupie podręczników w zróżnicowanym kontekście i postaci. Homoseksualizm nazywano m.in. nietypowością seksualną, zaburzeniem, „,kierunkiem” wyznaczającym drogę, z której młodzi ludzie mogą zawrócić czy - dopiero w ostatnich wersjach podręcznika - orientacją seksualną. Kontekstem dla wprowadzania zmian stały się opisane w pracy starcia pomiędzy podmiotami strzegącymi „starego” porządku a zwolennikami jego zmiany, sprzeciwiającymi się normatywnemu i obowiązkowemu charakterowi zachowań heteroseksualnych.

Slowa kluczowe: podręczniki; homoseksualizm; panika moralna; wojna kulturowa

\section{O PODRĘCZNIKOWEJ (HOMO)SEKSUALNOŚCI W KONTEKŚCIE POLSKIM - OD PANIKI MORALNEJ DO WOJNY KULTUROWEJ ${ }^{1}$}

Jedną z zasadniczych zmian, które zaszły w ciągu ostatnich 100 lat i dotyczą krajów wysoko uprzemysłowionych miało stać się odejście od kościelnej regulacji

1 W niniejszym opracowaniu prezentuję wybrane wnioski zamieszczone w pracy doktorskiej pt. Modele wychowania seksualnego w szkole gimnazjalnej i ponadgimnazjalnej (Smoter, 2016). 
moralności (zob. Bieńko, 2013, s. 163) oraz przejście do sposobu organizowania zachowań za pośrednictwem medycyny, psychologii, polityki, pomocy społecznej i w końcu edukacji (zob. Weeks, 2012, s. 36). Dwudziestowieczne przemiany obyczajowe doprowadziły do sytuacji, w której intymność jest regulowana w znacznie mniejszym niż wcześniej stopniu przez powszechnie obowiązujące normy i dyrektywy kulturowe, wobec czego może być kształtowana przez arbitralne decyzje jednostek oraz uzgodnienia pomiędzy nimi. Takie warunki sprzyjają wybuchom panik moralnych, cechujących się zidentyfikowaniem przez jakąś grupę bądź jakieś grupy określonego zjawiska w kategoriach odbiegającego od normy czy zagrażającego dominującemu porządkowi społecznemu. Czasem jej skutkiem staje się wojna kulturowa toczona w imię afirmacji tradycyjnych koncepcji życia i promująca daną ,normalność”.

W niniejszym artykule oba fenomeny stanowią kontekst analiz dla homoseksualności obecnej w podręcznikach do zajęć z zakresu wychowania do życia w rodzinie. W ciągu ostatnich kilkunastu lat kwestie odnoszące się do homoseksualizmu występowały w tej grupie podręczników w zróżnicowanym kontekście i postaci. Homoseksualizm określano m.in. jako nietypowość seksualną, zaburzenie, „kierunek” wyznaczający drogę, z której dorastający mogą zawrócić, czy w ostatnich wersjach podręczników - orientację seksualną. Kontekstem dla wprowadzanych zmian stały się w tym opracowaniu starcia między podmiotami, które strzegą „starego” porządku, a zwolennikami jego „obalenia” lub modyfikacji, przeciwstawiającymi się normatywnej i obowiązkowej heteroseksualności.

\section{SEKSUALNOŚĆ - PRZEOBRAŻENIA I PRZEŁOMY}

Szczególny przełom w postrzeganiu seksualności nastąpił pod koniec lat 60 . XX w. i na początku lat 70. XX w. Początek nowej ery seksualnej wolności datuje się na rok 1968, wskazując na narastające wówczas zjawisko życia seksualnego młodzieży, które szło w parze z wcześniejszym osiąganiem dojrzałości płciowej w zachodnim kręgu kulturowym. Problem libido i jego wyzwolenia nie miał dotyczyć tylko fragmentarycznej (nawet jeśli istotnej) kwestii seksu, lecz miał się stać nośnikiem pytania o wolność jednostki. Proces owego wyzwalania miał dwa aspekty. Pierwszym z nich było uzyskanie „wolności od”, a wraz z nią możliwości wyboru w zakresie seksu. Drugi aspekt to „wolność do”, czyli prawo do wyrażania swej prawdziwej natury czy tożsamości seksualnej. Wyzwolenie seksualne stało się możliwe m.in. dzięki wprowadzonej na rynek pigułce seksualnej autonomizującej i uniezależniającej genitalne akty seksualne od prokreacji (zob. Giddens, 2006, s. 207; Reinhard, 2009, s. 85).

W analizach podjętych przez badaczy okresu ,rewolucyjnego" i ,porewolucyjnego" (między latami 60. XX w. a pierwszą dekadą XXI w.) zwraca się uwagę na osłabienie znaczeń, jakie niosą za sobą rodzina czy Kościół, co wiąże się z no- 
wymi wzorami życia intymnego. Miałby on być oparty bardziej niż kiedykolwiek wcześniej na sprawczości seksualnej oraz na wyborze. Zarówno antykoncepcja, jak i działania feministek miały więc pociągać za sobą przemiany w sferze intymnej i relacjach społecznych. Łączyło się to z dążeniem do samorealizacji jednostek tworzących te relacje oraz z koncentracją na doświadczeniu indywidualnym (por. Czykwin, 2013, s. 229). W związku z tym uznaje się niekiedy, że rewolucja seksualna niesie za sobą podwójne wyzwolenie: w małżeństwie i od małżeństwa (za: Himmelfarb, 2007, s. 72). Jednak w czasie momentów krytycznych krystalizowało się zainteresowanie wieloma kwestiami (w tym normami życia rodzinnego, relacjami międzypłciowymi, naturą kobiecej seksualności, różnorodnością seksualną, relacjami między dorosłymi i dziećmi). Debaty wokół tych kwestii pojawiały się w większości krajów Zachodu w ostatnich dziesięcioleciach, gdzie dyskusje o seksualności można uznać za rozmowy o naturze społeczeństwa (zob. Weeks, 2012, s. 44-45).

\section{POTRANSFORMACYJNY SYSTEM SPOŁECZNYCH ODNIESIEŃ DO SEKSUALNOŚCI}

Omawiana tu rewolucja seksualna dotarła do Polski z opóźnieniem. Przełomem według niektórych badaczy okazał się rok 1989 i tzw. mała rewolucja seksualna otwierająca proces „,nadrabiania zaległości” w dziedzinie seksualności, które wyłoniły się przy porównaniu Polski i państw zachodnich (zob. Lew-Starowicz, 1988, s. 139). Do tych przemian przyczyniły się wolność handlu, słowa i druku, jaka „otworzyła się” dla Polski w okresie transformacji ustrojowej. Środki masowego komunikowania zaczęły być traktowane jako odpowiedzialne za ,produkcję" osobowości, życia, myślenia oraz wartościowania człowieka (zob. Buksiński, 2001, s. 41). Miały również przyczynić się do wzrostu znaczenia seksu, potrzeb z zakresu wychowania seksualnego czy tolerancji wobec innych niż heteroseksualna orientacji seksualnych (zob. Lew-Starowicz, 1988, s. 139). W pierwszych dziesięcioleciach XXI w. wskazywano też na większą otwartość w odniesieniu do seksualności w życiu społecznym (wraz z seksualizacją przestrzeni publicznej; zob. Waszyńska, Zielona-Jenek, 2016, s. 355-362), promowanie tego, co nazwano zdrowiem seksualnym (zob. Lew-Starowicz, Lew-Starowicz, 2003, s. 1-6) oraz nowych metod badania seksualności (zob. Izdebski, 2012, s. 52-53, 71-74). Osłabły rygory instytucjonalizacji seksu - nie jest już sprowadzany jedynie do roli „rekwizytu” w funkcjonowaniu innych ,urządzeń społecznych”, a w szczególności rodziny. Nie oznacza to zanegowania znaczenia tej instytucji, lecz jedynie wskazuje na prawną dopuszczalność seksu także poza nią (zob. Filar, 1995, s. 21). W rezultacie tych przeobrażeń tworzy się taka obyczajowość seksualna, w obrębie której wspólistnieją sprzeczne wartości, normy czy wzory zachowań niedające się uporządkować według jednej zasady czy hierarchii oraz „cieszące 
się" zróżnicowanym poziomem akceptacji (zob. Lew-Starowicz, 1993; Mariański, 2010, s. 38).

Wraz z tymi przeobrażeniami wzorów rządzących życiem seksualnym doszło do utworzenia się nowych granic dla systemu społecznego. Początki demokracji w Polsce wiązały się przede wszystkim z jej proceduralnym rozumieniem. Wynikało to z konieczności zbudowania prawnego instrumentarium, który miał pozwolić obywatelom i obywatelkom na korzystanie z przysługujących im praw (zob. Skowrońska, Sztop-Rutkowska, 2013, s. 51), w tym również z praw seksualnych. Społeczeństwo obywatelskie miało być rozumiane jako przestrzeń, w której normy kulturowe i wykładnia praw są wyraźnie zdefiniowane (zob. m.in. Foley, Edwards, 1996), obywatele są chronieni przez państwo za pomocą umowy społecznej, a ruchy społeczne działają już na poziomie lokalnym, gdzie normy kulturowe bywają uznawane za sporne. W tym ujęciu demokracja miała pozwolić na równoprawność podmiotów sfery publicznej. Przynależna demokracji pluralizacja życia politycznego oraz rozwój niezależnych mediów miały dalej umożliwić rozwój publicznego dyskursu i jego stopniową liberalizację (por. Jakubowski, 2011, s. 34). Tymczasem zjawiska te wywołały szereg napięć i antynomii (por. m.in. Reykowski, 1993). Pluralizm poglądów zaczęto niekiedy kojarzyć z zagrożeniem, chaosem czy nie-porządkiem sfery publicznej i odczytywać go jako zarzewie podziałów społecznych. Tuż po 1989 r. przyjęły one postać podziałów socjopolitycznych na obóz solidarnościowy oraz „postpeerelowski” (zob. np. Grabowska, Szawiel, 2001, s. 215), lecz po przełomowym dla systemu partyjnego roku 2005 (zob. Jakubowski, 2011) punkt ciężkości tego podziału został przeniesiony na konflikt między środowiskami określanymi w dyskursie społecznym jako „konserwatywne” i „liberalne”. Takie ujęcie sugerowałoby istnienie dwóch zdychotomizowanych i będących w opozycji obozów, sprawa okazuje się jednak bardziej skomplikowana, a same podziały - i liczniejsze, i bardziej niejednoznaczne. Nie są one obserwowalne wyłącznie jako walki prowadzone między obozami polskiej sceny politycznej, uwidaczniają się bowiem także w relacjach między innymi instytucjami czy podmiotami społecznymi oraz wewnątrz instytucji.

\section{WOJNY KULTUROWE I ICH SPECYFIKA}

Działania mogą stanowić zarzewie tego, co na potrzeby tego tekstu zostanie potraktowane jako wojna kulturowa, czyli działanie stabilizujące bądź podważające wartości, które powinny kierować ludźmi w ich życiu indywidualnym i być respektowane w skali społecznej. Chodziłoby tu o moralne fundamenty politycznie stanowionego ładu społecznego, będącego wyrazem (określonego) dobra. Ma ono promować (określoną) „,normalność” czy „prawdziwe” wartości. Taka wojna jest toczona w imię afirmacji tradycyjnych koncepcji życia (,uniwersalizmu”), zderzonych z tym, co Roger Scruton nazwał „kulturą odrzucenia” (,relatywi- 
zmu") (za: Burszta, 2013, s. 10). W przypadku tak zdefiniowanych wojen kulturowych „linie bojowe” najczęściej można uznać za jasno wytyczone. Za ulubione miejsca bitew przyjmuje się demokratyczny proces polityczny, a każda ze stron stara się pozyskać jak najwięcej przychylności władzy państwowej (zob. Berger, 1999; Himmelfarb, 2007, s. 159, 168).

W eseju The American Culture War James D. Hunter (1998, s. 2-14, za: Himmelfarb, 2007, s. 158) rozróżnił poziomy, na których wyrażają się przeciwstawne systemy oraz wizje towarzyszące wojnom kulturowym. Na jednym z nich toczą się batalie wokół aborcji, wielokulturowości czy edukacji seksualnej, na kolejnym zaś rozgrywa się rywalizacja ideałów moralnych dotyczących tego, jak obywatele powinni porządkować życie publiczne i jaką dbałość mają o nie wykazywać. Rywalizacja ta uwypukla odmienne zasady kryjące się za tymi ideałami. Z jednej strony zasady te wynikają z „obiektywnych” norm „mówiących” o tym, co jest dobre i prawdziwe, kim jesteśmy i jak powinniśmy żyć. $Z$ drugiej natomiast podstawą zasad stają się normy warunkowe oraz relatywne, których źródłem jest jednostkowe doświadczenie i wiara w autonomię wyboru. W każdym przypadku wojna kulturowa konfrontuje nas z problemem ustalenia ,granic społecznej spójności” oraz znalezienia sposobów „spierania się i mediacji” (zob. Berger, 1999).

W przypadku wojen dotyczących seksualności (wojen seksualnych) sprawa wydaje się wyjątkowo złożona - uznawana za schizoidalną „,natura” teraźniejszości jest z jednej strony naznaczona moralnym chaosem, a z drugiej - religijno-moralnym ożywieniem (zob. Himmelfarb, 2007, s. 136), i jako taka staje się nierzadko ,poligonem”, na którym dochodzi do starć pomiędzy zwolennikami seksualnej różnorodności i seksualnej jednorodności (zob. Cossman, 2007). Na potrzeby tego artykułu przyjmuję, że społeczny system seksualny nie stanowi monolitu czy wszechmocnej struktury, a społeczeństwa ludzkie stanowią przestrzeń dla bitew nad seksualnymi definicjami, ocenami czy przywilejami. Rozgrywają się one zazwyczaj między głównymi ,producentami” ideologii seksualnych (w tym przedstawicielami instytucji leczniczych, świata mediów, oświaty, partii politycznych czy kościołów) a grupami, które w rozumieniu tych pierwszych zniekształcają dominujące i uprawnione doświadczenia seksualne, stanowiąc zagrożenie dla zastanych wartości.

\section{OD PANIK MORALNYCH DO PANIK SEKSUALNYCH}

Punktem zapalnym dla wojen seksualnych okazuje się nierzadko zjawisko paniki moralnej. Miałaby się ona pojawiać wtedy, gdy jedna lub więcej grup (określanych mianem „generatorów moralności”) zidentyfikowałaby zjawisko społeczne i kulturowe w kategoriach społecznie problematycznego i/lub odbiegającego od normy, zagrażającego dominującemu porządkowi społecznemu i łączącym się z nimi wartościom (zob. Wargacki, 2009; Soin, 2011). W dalszej ko- 
lejności „generatorzy moralności” identyfikowaliby osoby lub grupy osób, które są postrzegane jako urzeczywistnianie zagrożenia, a następnie by zniekształcali i wyolbrzymiali problem społeczny. Zazwyczaj sięga się po statystyki i media, aby to zjawisko uwidocznić w sferze publicznej. Widoczność miałaby dalej generować intensywne i nadmierne reakcje publiczne właśnie w postaci paniki moralnej. Uznanie określonej osoby bądź osób jako ucieleśnienia problemu społecznego ułatwia zaś wykazywanie w odniesieniu do nich określonych reakcji (zob. Cohen, 1972).

Przyjmuje się, że paniki moralne często pojawiają się w historycznie określonych chwilach konfuzji i niejednoznaczności, gdy granice między legalnym i nielegalnym zachowaniem wydają się wymagać przedefiniowania i przekwalifikowania (zob. Cohen, 1972). Panikę moralną ożywia opowieść, narracja, dyskurs o jakimś zagrożeniu, snuty przez różnego rodzaju autorytety. Kiedy opowieść przyjmuje się za rzeczywistość, zgodnie z logiką paniki moralnej zaczyna ona potwierdzać nasze przekonanie. Jeśli coś do tego wizerunku nie pasuje, wówczas często to usuwamy. Nieważna jest rzeczywista skala zagrożenia i to, czy ono realnie istnieje. Nieważny jest także podmiot zagrożenia. Istotne okazuje się za to, że przyczynia się do rozchwiania wartości społecznych (zob. Cohen, 1972). W odniesieniu do seksualności „generatorzy moralności” są skoncentrowani na kwestiach lokalnych, jednak ów często wąski zasięg nie wyłącza z nich takich kategorii, jak płeć, wiek i władza. Te ostatnie umożliwiają wytyczenie granic dla tego, co jest uważane za „normalne” w danym kontekście. Tematy moralnych panik wiążących się z seksualnością nierzadko wydają się być pojmowane jako „kryzys”. Naprzeciw takiemu ujęciu wychodzą głosy ekspertów - dysponentów określonych dyskursów, posługujących się często zmanipulowanymi danymi wspierającymi określoną wersję rzeczywistości. Takie „podparcie" zwykle prowadzi do skierowania uwagi państwa na kwestie regulacji i kontroli seksualności oraz często pociąga za sobą również legislacyjne i prawne decyzje (zob. Seidman, 2012).

Przyjmując omówiony tryb analiz, można zauważyć, że panika moralna (w tym przypadku: seksualna) krystalizuje pewne obawy i niepokoje, lecz często zajmuje się nimi nie przez poszukiwanie przyczyn problemów i warunków ich powstawania, ale właśnie przez znalezienie ,diabłów ludowych” w określonej grupie społecznej (często uznawanej za niemoralną, zdeprawowaną czy zdegenerowaną) (zob. Weeks, 1998). Ten typ paniki rzadko rozwiązuje rzeczywisty problem, ponieważ osoby ją wzniecające czerpią z istniejących wcześniej dyskursywnych konstrukcji ofiary w celu uzasadnienia „leczenia” określonej społecznej „wady”. W efekcie tworzą się społeczne hierarchie „,dobrych” i „złych” praktyk seksualnych, a czasami też „dobrych” i „złych” członków społeczeństwa w przypadku realizacji przez nich konkretnych seksualnych aktywności (zob. Foucault 1995). 


\section{POLSKA PANIKA (HOMO)SEKSUALNA - CASUS TREŚCI PODRĘCZNIKÓW DO ZAJĘĆ WYCHOWANIA DO ŻYCIA W RODZINIE}

Według niektórych badaczy seksualności omówione wyżej podziały uwidaczniają się w sposób szczególny w polskim kontekście kulturowym. Jednym z obiektów starć miedzy dysponentami różnego rodzaju dyskursów okazują się treści „zasilające” wychowanie seksualne realizowane w oficjalnym programie szkolnym (zob. m.in. Chustecka, 2011; Kochanowski, Kowalczyk, Lew-Starowicz, Wąż, 2013), a punktem wyjścia w jego ocenie i formułowaniu dlań postulatów „ku zmianom” jest m.in. zawartość podręczników szkolnych. Od momentu wprowadzenia do szkół pierwszego podręcznika odnoszącego się do wychowania seksualnego jego treść budzi kontrowersje, stając się przedmiotem dyskusji, a niekiedy też wojen kulturowych, w których najbardziej widoczni w dyskursie publicznym są przedstawiciele skrajnych opcji światopoglądowych. „Przetrwaniu" części podręczników i realizacji zawartych w nich wytycznych co do wychowania seksualnego nie pomagały nawet rekomendacje ze strony środowisk eksperckich (por. Nowakowska, 1997, s. 78).

Osobnym problemem w polskiej obyczajowości jest krytyka wymierzona w określających siebie jako „neutralnych światopoglądowo” (a przynajmniej „niedeprawujących”) twórców literatury z zakresu edukacji seksualnej. Dochodziło do niej niekiedy niezależnie od „werdyktu” ministerialnego, który wiązał się z dopuszczeniem konkretnego podręcznika do „użytku” szkolnego. Krytyka ta, pociągając za sobą sprzeciw dysponentów określonych dyskursów, wiązała się dalej z podważaniem poprawności merytorycznej, dydaktycznej, wychowawczej, naukowej czy językowej treści podręcznika. Można go potraktować na potrzeby niniejszego artykułu nie w kategorii narzędzia zawierającego „proste” zestawienie wartości i intencji piszących, lecz jako wynik negocjacji i kompromisów pomiędzy decydentami, twórcami i dysponentami tych treści. Dzięki temu może być poddawany nie tyle „bezdyskusyjnej aprobacie”, co „dochodzeniom”, a dalej również różnego rodzaju „oskarżeniom”. Podstawą dla ich podjęcia może być przekonanie, że ów niesie za sobą określony model wychowania i kształcenia (por. Nocoń, 2009, s. 45; Rypel, 2012, s. 101), a ten ostatni może być odczytywany jako społecznie „pożądany” lub „niepożądany”, generujący niebagatelne skutki dla sposobów postrzegania określonych jednostek i grup. Wśród nich można wskazać na osoby nieheteroseksualne, w tym homoseksualne.

Obecność w tekstach podręcznikowych treści dotyczących orientacji seksualnych nie ma długiej historii. Na przestrzeni ostatnich kilkunastu lat podręcznikowy seksualizm okazał się być implicitnie heteroseksualizmem (zob. np. WOS. G. I. 1999; WOS. G. II. 1999). W okresie 1999-2001 w dyskursie podręcznikowym były obecne takie teksty, w których nie tylko nie definiowano homoseksualizmu, lecz także nie wzmiankowano o mniejszościach seksualnych (zob. WOS. 
G. I. 1999; WOS. G. II. 1999). W przypadku uwzględniania homoseksualizmu w swych rozważaniach autorzy w zasadzie nie skupiali się na jego przyczynach, zdarzało się jednak, że wskazywali na to, że nie ma w tym obszarze jednoznaczności. Homoseksualizm nazywano nietypowością seksualną (zob. WOS. WDŻWR. G. 2001) bądź traktowano jako „kierunek” wyznaczający drogę, z której młodzi ludzie mogą zawrócić (zob. WKD. G. 1999). Pozornie nie wartościowano aktywności homoseksualnej, np. wskazując, iż kontakty heteroseksualne są uznawane i realizowane przez społeczną większość, a te nieheteroseksualne - przez społeczną mniejszość (WOS. G. II. 1999). Nie miało to oznaczać akceptacji dla uwidocznienia osób homoseksualnych w społeczeństwie. W jednym z podręczników podkreślono wręcz, iż brak społecznej aprobaty skutkuje ukrywaniem faktu bycia osobą homoseksualną (WOS. G. II. 1999). Dodatkowo w jednym z tekstów podkreślono: „(...) szczególne zagrożenie zakażeniem HIV niosą częste zmiany partnerów seksualnych oraz niektóre formy kontaktów homoseksualnych" (WKD. G. 1999, s. 163), co można uznać za pośrednio łączące aktywność (homo) seksualną z kategorią ryzyka seksualnego. Jeśli chodzi o ten podręcznik, szczególne kontrowersje wzbudziło usytuowanie treści dotyczących homoseksualizmu w rozdziale „Zaburzenia rozwoju psychoseksualnego” i jednocześnie w sąsiedztwie fragmentu dotyczącego nakłaniania nieletnich do kontaktów seksualnych oraz możliwej penalizacji tych zachowań (zob. także: Pedofilia, kazirodztwo, homoseksualizm, 2010). W późniejszych wersjach tego podręcznika (z 2009 r.), pisząc o homoseksualizmie, traktuje się go w kategorii skłonności oraz wskazuje na jej możliwą odwracalność i skuteczność terapii reparatywnej. Treści te zostały zamieszczone obok fragmentu odnoszącego się do stanowiska Kościoła katolickiego wobec homoseksualizmu. Dopiero jednak wersja z 2011 r. przynosi prawdziwy przełom - ujmuje się tu bowiem homoseksualizm jako orientację seksualną, dostrzegając, że został wykreślony z rejestru chorób psychicznych przez przedstawicieli Światowej Organizacji Zdrowia. Ponadto omówiono skłonności homoseksualne kobiet i pojawiły się wzmianki o ruchu gejowskim. Osobno umieszczono stanowisko wzywające do szacunku i tolerancji, wynikające z zapisu w Konstytucji RP, oraz stanowiska grup wyznaniowych.

Skąd ta zmiana i jakie były jej skutki? Za jednego z inicjatorów można uznać członków Stowarzyszenia na Rzecz Lesbijek, Gejów, Osób Biseksualnych, Osób Transpłciowych oraz Osób Queer (LGBTQ) Pracownia Różnorodności (SPR) (zob. http://www.spr.org.pl/2011/08/24/kalendarium-pewnej-wedrowki). Analizując treści podręcznika Wędrując ku dorosłości... z 1999 r., uznali, że wąsko omówiona w nim kwestia homoseksualizmu zawiera szereg homofobicznych insynuacji (zob. Porożyński, 2004). We wznowieniu podręcznika z 2009 r. znalazły się zmiany części tekstu (w tym tej dotyczącej homoseksualizmu) pod kątem zapisu tzw. nowej podstawy programowej. Odczytanie go dalej jako homofobicznego stało się powodem wystosowania apelu, który w 2010 r. skierowali 
do MEN przedstawiciele Fundacji Wolnej Myśli. W odpowiedzi reprezentanci MEN stwierdzili, że przedmiotem dyskusji było wydanie podręcznika z $1999 \mathrm{r}$. W sierpniu 2010 r. członkowie SPR wystąpili do Elżbiety Radziszewskiej, rządowej pełnomocniczki ds. równego traktowania, stawiając zarzuty wobec rozdziału dotyczącego homoseksualizmu w wydaniu podręcznika z 2009 r. Zaapelowali o wycofanie podręcznika $\mathrm{z}$ uwagi na to, że nie uwzględniono w nim aktualnego stanu wiedzy naukowej. Miało to stanowić naruszenie rozporządzenia Ministra Edukacji Narodowej z dnia 8 czerwca 2009 r. w sprawie dopuszczania do użytku w szkole programów wychowania przedszkolnego i programów nauczania oraz dopuszczania do użytku szkolnego podręczników (Dz.U. 2009, nr 89, poz. 730). Radziszewska wystąpiła do MEN z prośbą o ponowną analizę podręcznikowych treści pod kątem źródeł i charakterystyki homoseksualizmu. We wrześniu $2010 \mathrm{r}$. zawiadomiła SPR, iż „w obecnej formie fragmenty podręcznika dotyczące osób nieheteroseksualnych budzą wątpliwości”, bo - choć wiele zagadnień odnoszących się do homoseksualizmu nie znalazło jednoznacznego i naukowego wytłumaczenia - treści, które podaje się wrażliwemu i młodemu odbiorcy, powinny mieć charakter obiektywny oraz pozbawiony uprzedzeń (zob. http://www.sejm. gov.pl/Sejm7.nsf/InterpelacjaTrescxsp?key=0A293252; Haber, 2009).

Wówczas MEN zwrócił się do rzeczoznawców z prośbą o odniesienie się do zarzutów stawianych przez SPR. W październiku 2010 r. do MEN zaczęły trafiać listy w obronie podręcznika od osób prywatnych oraz pracowników Fundacji „Wiedzieć Jak” (zob. Kałach, 2009). Były one identyczne pod względem treści (sformułowano je na podstawie wzoru pobranego $\mathrm{z}$ jednej ze stron internetowych), w każdym z nich pojawił się też (,,potwierdzający” prawdziwość podręcznikowych treści) cytat z książki wydanej w 1990 r. Przekleństwo Androgyne. Transsesksualizm: mity i rzeczywistość Kazimierza Imielińskiego i Stanisława Dulko. W odpowiedzi na to SPR skontaktował się z dr. Dulko i uzyskał od niego odmienne stanowisko odnoszące się do charakteru i źródeł homoseksualności. Zostało ono skierowane do MEN wraz z odpowiedzią na inne argumenty obecne w listach protestacyjnych. SPR zwróciło się również do MEN z prośbą o zajęcie stanowiska w sprawie podręcznika. W listopadzie 2010 r. z odpowiedzi sformułowanej przez MEN można było wywnioskować, że zastrzeżenia zostały przekazane do rozpatrzenia osobom wcześniej recenzującym podręcznik. Podtrzymały one swoje pozytywne o nim opinie, za zasadne uznając jednak usunięcie przepisów kodeksu karnego umieszczonych w towarzystwie homoseksualizmu. Jeden z rzeczoznawców (Józef Augustyn SJ) zauważył też potrzebę przeformułowania niektórych stwierdzeń odnośnie do homoseksualizmu. W czerwcu $2011 \mathrm{r}$. członkowie SPR wskazali na wątpliwości odnoszące się do procedury opiniowania podręczników. Niemniej pewne zmiany wprowadzone w podręczniku stały się faktem i w zmodyfikowanym kształcie trafił on w 2011 r. na półki księgarń (http:// www.spr.org.pl/2011/08/24/kalendarium-pewnej-wedrowki). Przyczyny wpro- 
wadzenia modyfikacji zostały oficjalnie wytłumaczone potrzebą (ponownego?) dostosowania treści podręcznika do nowej podstawy programowej przedmiotu (zob. Janik, 2011). Nie była to jednak jedyna interpretacja. Praktyki „narzucania” zmian w podręcznikowym tekście zostały zinterpretowane przez rzeczoznawcę tekstu, J. Augustyna SJ (2013), jako wyraz „batalii o podręczniki, jaką prowadzą z Ministerstwem Edukacji Narodowej środowiska gejowskie". Działania miałyby stanowić jeden z etapów dążeń, których cel to wprowadzenie paraleli między tzw. małżeństwami homoseksualnymi a heteroseksualnymi. Ów rzeczoznawca wskazał jeszcze na bierność środowisk reprezentujących „normalną, zdrową rodzinę w odniesieniu do programów i podręczników do zajęć wychowanie do życia w rodzinie". Paradoksalnie jednak przedstawiciele niektórych środowisk sprzeciwili się wprowadzanym w omawianym tu podręczniku zmianom, czego wyrazem stały się działania medialne podjęte niedługo po ujawnieniu ingerencji SPR w odniesieniu do podręcznikowych treści. Podczas gdy dziennikarze portalu fronda.pl konstruowali aprobatę dla dotychczasowej zawartości podręcznika popartą głosem eksperta, np. ówczesnego rzecznika MEN Grzegorza Żurawskiego: „Ministerstwo nie może wycofać podręcznika tylko dlatego, że jakaś grupa osób nie zgadza się z teoriami wyłożonymi przez uczonych, którzy go napisali” (zob. Homo-lobby naciska na MEN ..., 2010), dziennikarze pch.24.pl postawili na zasianie „ziaren niepokoju” co do losów polskiej szkoły, która może zostać opanowana przez pederastów. Na przeszkodzie temu niekoniecznie stanęłoby MEN, istniało więc poważne ryzyko odnoszące się do ,promocj[i] homoseksualizmu w polskich szkołach oraz pozbyci[a] się elementów, które afirmują normalną rodzinę" (zob. Musiał, 2013). Za szczególnie interesujące można w tym kontekście uznać działania pracowników Fundacji Mamy i Taty, która pod koniec 2010 r. opublikowała raport pt. „Przeciw wolności i demokracji. Strategia polityczna lobby LGBT w Polsce i na świecie: cele, narzędzia, konsekwencje". Można w nim odnaleźć pogłębioną diagnozę celów, strategii i praktyk działania środowisk homoseksualnych w Polsce i na świecie, a także listę postulatów, do których rzekomo będą dążyć te środowiska. Wśród nich wymieniono: zabiegi zmierzające do penalizacji tzw. mowy nienawiści z uwagi na orientację seksualną; zaognienie walki z wszelkimi podmiotami, które nie aprobują poglądów wyrażanych przez środowiska LGBT i wyrażają publicznie swoje zdanie w tej kwestii; zrównanie małżeństw oraz związków partnerskich; walkę, dla której punktem odniesienia jest prawo do adopcji dzieci przez homoseksualistów; wdrożenie do praktyki szkolnej tzw. edukacji seksualnej, która uwzględnia przekonania ideologów LGBT dotyczące orientacji seksualnej (zob. Fundacja Mamy i Taty, 2010). Ostatni punkt znalazł wyraz w procesie „majstrowania” w podręcznikach. Jak zauważyła jedna z dziennikarek portalu Deon.pl: „Ostatni postulat (...) może wydawać się błahy. W rzeczywistości jest to jednak sprawa najwyższej wagi, ponieważ dzieci spędzają w szkole jedną czwartą swojego życia. To wystarczy, aby zakwestionować 
wpojone im w domu rodzinnym zasady" (zob. Guziak-Nowak, 2013). Jak podkreśliła dalej: „Świadomi tego faktu aktywiści homoseksualni proponują rewolucję w szkolnych podręcznikach, z których uczniowie czerpią wiedzę o otaczającym ich świecie" (zob. Guziak-Nowak, 2013).

Niewątpliwie każda ze wskazanych wypowiedzi stanowi swego rodzaju reakcję na „kryzys” normatywny wywołany chęcią „zamieszania” przez środowiska homoseksualne w dotychczasowym ,porządku seksualnym”, w którym homoseksualizm traktowany był jako swoista aberracja. Celem podmiotów strzegących „starego" porządku wydaje się nie tylko jego obrona i ochrona, lecz także odbudowa już naruszonego przez „homo-lobby” ładu społecznego. W wymiarze ideologicznym działania te wydają się pełnić funkcję wyzwalającą, uzmysławiając „reszcie świata”, że jest o co i o kogo (o dzieci) „,walczyć”. Ingerencje „homo-lobby" w kształt podręcznikowych treści to tym samym palący problem społeczny niepodlegający rozwiązaniom kompromisowym. Takich zresztą nie zaproponowali zwolennicy alternatywnego porządku (homo)seksualnego. Wyrazem ich aktywności miały się stać nie tylko dążenia przedstawicieli Fundacji Wolnej Myśli czy SPR, ale i „popierające” te zmiany praktyki medialne. Można tu wymienić szereg artykułów napisanych w obronie zmian, które pojawiły się w tym czasie w przestrzeni publicznej. Mowa choćby o jednoznacznym stanowisku pracowników portalu organizacji pozarządowych ngo.pl (zob. Szmit, 2010) czy dziennikarzy „Gazety Wyborczej” (zob. Lewińska, 2010) i tygodnika „Przegląd” (zob. Chmielewska, Żukowski, 2006). Kontynuację omówionych praktyk dyskursywnych można zaś powiązać z wydaniem raportu pt. „Szkoła milczenia. Sprawozdanie z przeglądu treści szkolnych podręczników do biologii, wiedzy o społeczeństwie i wychowania do życia w rodzinie pod kątem przedstawienia w nich problematyki LGBTQ i treści homofobicznych" autorstwa Jacka Kochanowskiego i in. (2013). We wnioskach raportu podkreślono:

(...) podręczniki do biologii, wiedzy o społeczeństwie oraz wychowania do życia w rodzinie używane w gimnazjach i szkołach ponadgimnazjalnych nie poruszają problematyki LGBTQ tam, gdzie mogłoby to mieć miejsce, lub przedstawiają ją sprzecznie z ustaleniami nauki, ponadto większość podręczników poruszających tę problematykę przedstawia ją w sposób ocenny i zgodnie ze światopoglądem zakładającym niechęć wobec osób LGBTQ. (Kochanowski i in. 2013, s. 179)

Na przestrzeni ostatnich lat podstawa programowa zajęć wychowania do życia $\mathrm{w}$ rodzinie miała $\mathrm{w}$ założeniu pozwolić uczniom m.in. na zapoznanie się ze złożonością wiedzy o życiu seksualnym, regułach świadomego i odpowiedzialnego rodzicielstwa, wartościach, które dotyczą rodziny, życia w fazie prenatalnej oraz o tym, co służy świadomej prokreacji w tych aspektach (Haber, 2009; Podstawa programowa przedmiotu wychowanie do życia w rodzinie. II etap edukacyjny; Podstawa programowa - wychowanie do życia w rodzinie. Szkoła pod- 
stawowa - klasy IV-VIII). Zapowiadane już pod koniec 2016 r. i wprowadzane od 2017 r. zmiany w tym obszarze w zasadzie nie przyniosły przełomu. Zapis w nowych wersjach podstawy programowej ${ }^{2}$ wydaje się stanowić krok w kierunku standaryzacji fundamentu moralnego dla wychowania seksualnego w szkole, w której kwestie dotyczące LGBTQ są nie tyle negowane, co praktycznie niewidoczne. Krytycy takiego stanu rzeczy zwracają uwagę na to, że w nowym zapisie nie ma mowy o innej niż heteronormatywna orientacji seksualnej (Federacja na Rzecz Kobiet i Planowania Rodziny, 2019). Łączy się to z promocją jedynej adekwatnej wizji co do tego, jak powinno funkcjonować „zdrowe” społeczeństwo. Byłoby ono oparte na wartościach mocno sprzężonych ze światopoglądem katolickim, nie zostawiając zbyt wiele miejsca osobom, które wypisują się z tego schematu (Kozłowska, 2017), w tym przede wszystkim osobom nieheteroseksualnym (Dunajska-Minkiewicz, 2017). W takim ujęciu pozorna okazuje się wieloperspektywiczność rozumienia związków interpersonalnych - implicite małżeńskich i otwartych na prokreację. Obszary te można uznać za nierozdzielne i nienegocjowalne.

Zmiana $\mathrm{w}$ treści podstaw programowych została tymczasem pozytywnie przyjęta przez przedstawicieli niektórych prawicowych środowisk, którzy podkreślili: „Dzięki interwencji rodziców i organizacji prorodzinnych resort edukacji usunął z nowej podstawy programowej »Wychowania do życia w rodzinie« postulaty środowisk LGBT” (lml, 2017; zob. także: ,GPC”: wychowania do życia w rodzinie..., 2017). Mimo to nadal postulowano wzmocnienie w zapisie podstawy programowej roli małżeństwa jako trwałej relacji zawiązanej między kobietą i mężczyzną, stanowiącej fundament rodziny (MA, 2017).

2 Chodzi tu o następujące dokumenty: 1) podstawę programową zajęć WDZ dla szkoły podstawowej i branżowej szkoły I stopnia wynikającą z rozporządzenia Ministra Edukacji Narodowej z dnia 14 lutego 2017 r. w sprawie podstawy programowej wychowania przedszkolnego oraz podstawy programowej kształcenia ogólnego dla szkoły podstawowej, w tym dla uczniów z niepełnosprawnością intelektualną w stopniu umiarkowanym lub znacznym, kształcenia ogólnego dla branżowej szkoły I stopnia, kształcenia ogólnego dla szkoły specjalnej przysposabiającej do pracy oraz kształcenia ogólnego dla szkoły policealnej (Dz.U. 2017, poz. 356 ze zm.; Dz.U. 2018, poz. 1679), 2) podstawę programową zajęć WDZ dla czteroletniego liceum ogólnokształcącego i pięcioletniego technikum, której zapis jest obecny w rozporządzeniu Ministra Edukacji Narodowej z dnia 30 stycznia 2018 r. w sprawie podstawy programowej kształcenia ogólnego dla liceum ogólnokształcącego, technikum oraz branżowej szkoły II stopnia (Dz.U. 2018, poz. 467), 3) podstawę programową zajęć WDZ dla dotychczasowych szkół ponadgimnazjalnych wynikającą z rozporządzenia Ministra Edukacji Narodowej z dnia 27 sierpnia 2012 r. w sprawie podstawy programowej wychowania przedszkolnego oraz kształcenia ogólnego w poszczególnych typach szkół (Dz.U. 2012, poz. 977 ze zm.; Dz.U. 2014, poz. 803; Dz.U. 2016, poz. 895). Pełny wykaz tych dokumentów można znaleźć na stronie: http://www.wdz.edu.pl/dla-nauczyciela/akty-prawne. 


\section{ZAKOŃCZENIE}

Analizując wojny seksualne, przyjmuje się, że znaczenia, sposoby organizacji społecznej, zasady i normy oraz podziały między „dobrymi” a „złymi” odmianami płciowości są konsekwencją wpływów społecznych. Łączą się one z przypisywaniem seksualności społecznego bądź naturalnego charakteru. Taki sposób jej ujmowania nie tylko wiąże ją z polityką i moralnością (zob. Seidman, 2012, s. 264), lecz także ,pozwala” na to, by seksualność stała się przedmiotem konfliktów, które można nazwać „,sporami o granice” oraz o znaczenia przypisywane aktom i tożsamościom seksualnym. Omówiony w niniejszym opracowaniu ich przykład nie zmienia biegu historii „mówienia” o (homo)seksualności, potwierdza za to istnienie dychotomicznego porządku argumentacji ,za” i ,przeciw” dopuszczaniu jej określonego wariantu (por. Flatow, 2008). Działania przeciwników tych zmian można uznać za wpisujące się w schemat segregacji zachowań seksualnych opisany przez Gayle Rubin (1984, 2004). Autorka wskazuje w nim na normatywny i obowiązkowy charakter zachowań heteroseksualnych. Są one obdarzane akceptacją, stanowią ,niewidzialne centrum” i domniemany fundament społeczeństwa, kwintesencję siły tworzenia, podtrzymywania i utrwalania „,pozytywnego” porządku społecznego. „Inne” zachowania seksualne znajdują się poniżej granicy akceptacji i są uznawane w porządku zstępującym za coraz groźniejsze. Skutkiem tego staje się ,usuwanie” ich z horyzontu życia społecznego i/ lub marginalizowanie. Tymczasem osoby seksualnie „poprawne” są poważane, ich praktyki są traktowane jako legalne i społecznie wspierane. Seksualność „dobra”, „,normalna” i ,naturalna” powinna być heteroseksualna, monogamiczna, reprodukcyjna i niekomercyjna. Naruszający te zasady są „źli”, „nienormalni” lub „nienaturalni”, a ich zachowania są rozumiane jako praktyki niebezpieczne, patologiczne czy infantylne. Niekiedy domniemywa się występowanie u nich chorób psychicznych, wskazuje się na ich podejrzaną reputację, skłonności do przestępczości, pozbawia się wsparcia instytucjonalnego itd. Moralne piętno nadaje części seksualnych zachowań niski status i skutecznie sankcjonuje tych, którzy się od nich nie odżegnują. Intensywność tego piętna jest zakorzeniona w tradycjach religijnych i kulturowych, w ramach których neguje się „nieodpowiednie” związki i zapewnia ,wsparcie” tym właściwym (zob. Rubin, 1984, 2004). Przy przyjęciu założenia, że nie ma prawdy o seksualności poza językiem, dyskursem i władzą, każde dominujące stanowisko może zapoczątkować moralny podział pozostający w centrum wojen kulturowych przez następne lata (por. Weeks, 2012, s. 38). Wydaje się, że dotyczy to również podręcznikowej (homo)seksualności. 


\section{BIBLIOGRAFIA}

Augustyn, J. SJ (2013). Bierna batalia o podręczniki. Pobrane z: http://info.wiara.pl/doc/1504315. Bierna-batalia-o-podreczniki (dostęp: 7.05.2018).

Berger, P. (ed.). (1999). The Desecularization of the World: Resurgent Religion and World Politics. Grand Rapids: Eerdmans.

Bieńko, M. (2013). Seksualne opowieści kulturalnego człowieka. W: P. Żuk (red.), Kulturowo-polityczny AVATAR? Kultura popularna jako obszar konfliktów $i$ wzorów spolecznych (s. 156170). Warszawa: Oficyna Naukowa.

Buksiński, T. (2001). Społeczeństwo informatyczne i komunikacyjne. W: Społeczne problemy globalizacji (s. 33-49). Poznań: Wydawnictwo UAM.

Burszta, W.J. (2013). Kotwice pewności. Wojny kulturowe z popnacjonalizmem $w$ tle. Warszawa: Wydawnictwo Iskry.

Chmielewska, K., Żukowski, T. (2006). Szkoła uczuć (homofobicznych). Pobrane z: https://www. tygodnikprzeglad.pl/szkola-uczuc-homofobicznych (dostęp: 29.04.2019).

Chustecka, M. (2011). Analiza podręczników i podstawy programowej - przedmiot wychowanie do życia w rodzinie. W: M. Abramowicz (red.), Wielka nieobecna - o edukacji antydyskryminacyjnej $w$ systemie edukacji formalnej w Polsce. Raport z badań (s. 227-282). Warszawa: TEA.

Cohen, S. (1972). Folk Devils and Moral Panics: The Creation of the Modsand Rockers. London: MacGibbon \& Kee.

Cossman, B. (2007). Sexual Citizens. The Legal and Cultural Regulation of Sex and Belonging. Stanford: Stanford University Press.

Czykwin, E. (2013). Wstyd. Kraków: Oficyna Wydawnicza Impuls.

Dunajska-Minkiewicz, A. (2017). Program wychowania do życia w rodzinie: Nauka czy ideologia? Pobrane z: https://plus.kurierlubelski.pl/program-wychowania-do-zycia-w-rodzinie-naukaczy-ideologia/ar/12260088 (dostęp: 23.07.2019).

Federacja na Rzecz Kobiet i Planowania Rodziny (2019). Po Bożemu. Nowa podstawa programowa wychowania do życia w rodzinie. Pobrane z: http://federa.org.pl/po-bozemu-nowa-podstawaprogramowa-wychowania-do-zycia-w-rodzinie (dostęp: 21.07.2019).

Filar, M. (1995). Problemy reformy prawa karnego w Polsce w zakresie przestępczości seksualnej. Palestra, (7-8), 14-32.

Flatow, E. (2008). Problematyka homoseksualizmu w wybranych podręcznikach i publikacjach z zakresu edukacji seksualnej. Przeglad Terapeutyczny, (5), 1-20.

Foley, M.W., Edwards, B. (1996). The Paradox of Civil Society. Journal of Democracy, 7(3), 38-52. Foucault, M. (1995). Historia seksualności. Warszawa: Czytelnik.

Homo-lobby naciska na MEN, żeby wycofać niewygodny dla niego podręcznik. (2010). Pobrane z: http://www.fronda.pl/a/homo-lobby-naciska-na-men-zeby-wycofac-niewygodny-dla-niegopodrecznik,8057.html?page=4\& (dostęp: 28.04.2019).

Fundacja Mamy i Taty (2010). Raport: Przeciw wolności i demokracji Strategia polityczna lobby LGBT w Polsce i na świecie: cele, narzędzia, konsekwencje. Pobrane z: http://www.mamaitata. org.pl/gfx-upload/pliki/Przeciw_wolnosci_i_demokracji_Raport_Fundacji_Mamy_i_Taty. pdf (dostęp: 28.04.2019). 
Giddens, A. (2006). Przemiany intymności. Seksualność, miłość i erotyzm we współczesnych społeczeństwach. Warszawa: PWN.

„GPC”: wychowania do życia w rodzinie bez postulatów środowisk LGBT. (2017). Pobrane z: https://www.tvp.info/33578938/gpc-wychowania-do-zycia-w-rodzinie-bez-postulatowsrodowisk-lgbt (dostęp: 24.07.2019).

Grabowska, M., Szawiel, T. (2001). Budowanie demokracji. Podziały społeczne, partie polityczne i społeczeństwo obywatelskie w postkomunistycznej Polsce. Warszawa: PWN.

Guziak-Nowak, M. (2013). „Tęczowa” szkoła. Pobrane z: https://www.deon.pl/inteligentne-zycie/ obiektyw/art,517,teczowa-szkola.html (dostęp: 28.04.2019).

Haber, M. (2009). Odpowiedź podsekretarza stanu w Ministerstwie Zdrowia - z upoważnienia ministra - na zapytanie nr 4359 w sprawie zmian dotyczacych przedmiotu: wychowanie do życia w rodzinie. Pobrane z: http://orka2.sejm.gov.p1/IZ6.nsf/main/04FE5E61 (dostęp: 18.08.2018).

Himmelfarb, G. (2007). Jeden naród, dwie kultury. Warszawa: Wydawnictwa Akademickie i Profesjonalne.

http://www.spr.org.pl/2011/08/24/kalendarium-pewnej-wedrowki (dostęp: 11.03.2016).

http://www.wdz.edu.pl/dla-nauczyciela/akty-prawne (dostęp: 22.07.2019).

http://www.sejm.gov.pl/Sejm7.nsf/InterpelacjaTrescxsp?key=0A293252 (dostęp: 11.03.2016).

Hunter, J.D. (1998). The American Culture War. W: P.L. Berger (ed.), The Limits of Social Cohesion: Conflict and Mediation in Pluralist Societies (s. 1-37). New York: Perseus.

Izdebski, Z. (2012). Seksualność Polaków na początku XXI wieku. Studium badawcze. Kraków: Wydawnictwo UJ.

Jakubowski, J. (2011). Wpływ paranoi politycznej na dyskurs publiczny w Polsce. Refleksje, (3), $27-42$.

Janik, R. (2011). Podręcznik recenzowali o. Józef Augustyn SJ i prof. Nalaskowski. Pobrane z: http:// www.fronda.pl/a/quotpodrecznik-recenzowali-o-jozef-augustyn-sj-i-rofnalaskowskiquot, 13964. html (dostęp: 28.01.2018).

Kałach, M. (2009). Szkoły walczq z przedmatżeńskim seksem. Pobrane z: http://www.gazetawroclawska.pl/artykul/148217, szkoly-walcza-z-przedmalzenskimseksem,id,t.html?cookie =1 (dostęp: 20.05.2019).

Kochanowski, J., Kowalczyk, R., Lew-Starowicz, Z., Wąż, K. (2013). Szkoła milczenia. Sprawozdanie z przeglądu treści szkolnych podręczników do biologii, wiedzy o społeczeństwie $i$ wychowania do życia w rodzinie pod katem przedstawienia w nich problematyki LGBTQ i treści homofobicznych. Toruń: Stowarzyszenie Na Rzecz Lesbijek, Gejów, Osób Biseksualnych, Osób Transpłciowych Oraz Osób Queer „Pracownia Różnorodności”.

Kozłowska, A. (2017). W nowej podstawie programowej do WDŻ słowo ,rodzina” pada 173 razy, a słowo , seks” znajdziemy.... jedynie 2 razy. Pobrane z: https://natemat.pl/blogi/ponton/212755,w-nowej-podstawie-programowej-do-wdz-slowo-rodzina-pada-173-razy-a-slowo-seksznajdziemy-jedynie-2-razy-komentarz-pontonu (dostęp: 19.07.2019).

Lew-Starowicz, Z. (1988). Oseksie, partnerstwie i obyczajach. Warszawa: Wydawnictwo Współczesne.

Lew-Starowicz, Z. (1993). System wartości seksualnych współczesnych Polaków. Problemy Rodzi$n y,(3), 32-35$. 
Lew-Starowicz, Z., Lew-Starowicz, M. (2003). Zdrowie seksualne. Psychiatria w Praktyce Ogólnolekarskiej, 3(1), 1-6.

Lewińska, A. (2010). Homoseksualiści z przymusu albo z wyboru. Pobrane z: http://wyborcza. pl/1,76842,8291410,Homoseksualisci_z_przymusu_albo_z_wyboru.html (dostęp: 29.04.2019).

$\operatorname{lml}$ (2017). Prawdziwe wychowanie do życia $w$ rodzinie. MEN usuną z podstawy programowej postulaty środowisk LGBT. Pobrane z: https:/telewizjarepublika.pl/prawdziwe-wychowanie-do-zycia-w-rodzinie-men-usunal-z-podstawy-programowej-postulaty-srodowisk-lgbt,52471. html (dostęp: 24.07.2019).

MA (2017). Rezygnacja z postulatów LGBT to za mało. „,Wychowanie do życia $w$ rodzinie” musi mówić o rodzinie. Pobrane z: http://www.pch24.pl/rezygnacja-z-postulatow-lgbt-to-za-malo-wychowanie-do-zycia-w-rodzinie-musi-mowic-o-rodzinie,53739, i.html\#ixzz5vHGrDem6 (dostęp: 25.07.2019).

Mariański, J. (2010). Religia w społeczeństwie ponowoczesnym. Studium socjologiczne. Warszawa: Oficyna Naukowa.

Musiał, M. (2013). Szkoła dewiacji i patologii. Pobrane z: http://www.pch24.pl/szkola-dewiacji-ipatologii,14502,i.html\#ixzz5mhaPoBf4 (dostęp: 16.04. 2019).

Nocoń, J. (2009). Podręcznik szkolny w dyskursie dydaktycznym - tradycja i zmiana. Opole: Wydawnictwo Uniwersytetu Opolskiego.

Nowakowska, E. (1997). Niechciane maleństwo. Polityka, (10), 77-78.

Podstawa programowa przedmiotu wychowanie do życia w rodzinie. II etap edukacyjny: klasy IVVI. Pobrane z: https://men.gov.pl/wp-content/uploads/2011/02/4i.pdf (dostęp: 19.01.2018).

Podstawa programowa - wychowanie do życia w rodzinie. Szkoła podstawowa - klasy IV-VIII. Pobrane z: https://men.gov.pl/wp-content/uploads/2016/11/podstawa-progarmowa-wychowaniedo-zycia-w-rodzinie-klasy-iv-viii.pdf (dostęp: 21.01.2018).

Porożyński, P. (przyg. i oprac.). (2004). Raport: Mniejszości seksualne w polskich podręcznikach szkolnych do przedmiotu „Wychowanie do życia w rodzinie”. Szczecin: Stowarzyszenie Lambda.

Pedofilia, kazirodztwo, homoseksualizm. (2010). Pobrane z: https://queer.pl/artykul/186925/pedofilia-kazirodztwo-homoseksualizm (dostęp: 11.03.2019).

Reinhard, W. (2009). Życie po europejsku. Od czasów najdawniejszych do współczesności. Warszawa: PWN.

Reykowski, J. (1993). Psychologiczne antynomie demokracji. W: Z. Ratajczak (red.), Kolokwia psychologiczne (s. 21-37). Warszawa: Wydawnictwo Instytutu Psychologii PAN.

Rozporządzenie Ministra Edukacji Narodowej z dnia 8 czerwca 2009 r. w sprawie dopuszczania do użytku w szkole programów wychowania przedszkolnego i programów nauczania oraz dopuszczania do użytku szkolnego podręczników (Dz.U. 2009, nr 89, poz. 730).

Rubin, G. (1984). Thinking sex. Notes for a radical theory of the politics of sexuality. W: C.S. Vance (ed.), Pleasure and Danger: Exploring Female Sexuality (s. 267-293). Boston: Routledge \& Kegan Paul.

Rubin, G. (2004). Rozmyślając o seksie: zapiski w sprawie radykalnej teorii polityki seksualnej. Lewa Noga, (16), 164-224. 
Rypel, A. (2012). Ideologiczny wymiar dyskursu edukacyjnego na przykładzie podręczników języka polskiego z lat 1918-2010. Bydgoszcz: Wydawnictwo UKW.

Seidman, S. (2012). Społeczne tworzenie seksualności. Warszawa: PWN.

Skowrońska, M., Sztop-Rutkowska, K. (2013). Różnica - demokracja - edukacja. O potrzebie edukacji antydyskryminacyjnej. Pogranicze. Studia Społeczne, (13), 49-61.

Smoter, B. (2016). Modele wychowania seksualnego w szkole gimnazjalnej i ponadgimnazjalnej (Niepublikowana praca doktorska). Kraków.

Soin, M. (2011). Fakty, wartości i panika moralna. Studia Socjologiczne, (2), 147-163.

Szmit, P. (2010). Wychowanie do życia w rodzinie: podręcznik do homofobii. Pobrane z: https://publicystyka.ngo.pl/wychowanie-do-zycia-w-rodzinie-podrecznik-do-homofobii (dostęp: 28.04.2019).

Wargacki, S. (2009). Zjawisko paniki moralnej jako wyznacznik granic moralności. W: K. Rędziński (red.), Pedagogika XVIII (s. 7-20). Częstochowa: Wydawnictwo im. Stanisława Podobińskiego Akademii im. Jana Długosza.

Waszyńska, K., Zielona-Jenek, M. (2016). Zjawisko seksualizacji jako wyzwanie dla współczesnej edukacji. Studia Edukacyjne, (39), 351-375.

Weeks, J. (1998). The Sexual Citizen. Theory, Culture and Society, 15(3-4), 35-52.

Weeks, J. (2012). Wynalezienie seksualności. W: A. Kościańska (red.), Antropologia seksualności (s. 23-55). Warszawa: WUW.

\section{Wykaz skrótów podręczników poddanych analizie na potrzeby artykułu}

WDŻWR. G. 2009 Kalinowska, F. (2001). Wychowanie do życia w rodzinie. Piła: EfKa.

WKD. G. 1999 Król, T. (red.). (1999). Wędrując ku dorostości. Wychowanie do życia w rodzinie dla uczniów klas I-III gimnazjum. Kraków: Rubikon (autorzy: J. Wronicz, K. Maśnik, T. Król, M. Madej, G. Węglarczyk, W. Śledziński, B. Florek).

WKD. G. 2009 Król, T., Maśnik, K., Śledziński, W., Węglarczyk, G., Wronicz, J. (2009). Wędrując ku dorosłości. Wychowanie do życia w rodzinie dla uczniów klas I-III gimnazjum. Kraków: Rubikon.

WKD. G. 2011 Król, T., Maśnik, K., Śledziński, W., Węglarczyk, G., Wronicz, J. (2011). Wędrujac ku dorostości. Wychowanie do życia w rodzinie dla uczniów klas I-III gimnazjum. Kraków: Rubikon.

WOS. G. I. 1999 Kuczałek, I., Ura, D., Urban, M. (1999). Wiedza o społeczeństwie. Podręcznik z ćwiczeniami dla uczniów klasy I gimnazjum. Warszawa: Wydawnictwo Edukacyjne „Żak”.

WOS. G. II. 1999 Kuczałek, I., Ura, D., Urban, M. (1999). Wiedza o społeczeństwie. Podręcznik z ćwiczeniami dla uczniów klasy II gimnazjum. Warszawa: Wydawnictwo Edukacyjne „Żak”.

WOS. WDŻWR. Szczerba, K. (2001). Wiedza o spoleczeństwie. Wychowanie do życia w rodzinie. G. 2001 Podręcznik dla gimnazjum. Wrocław: Graf-Punkt. 


\section{SUMMARY}

In this article, the new regulation of intimacy and a cultural war became the context of analysis for homosexuality, which is present in textbooks for upbringing to life in the family. Over the last dozen or so years, homosexuality issues have occurred in this group of textbooks in a diverse context and form. Homosexuality was called, among others, sexual atypicalness, a disorder located alongside fragments about persuading minors to sexual contact, a "direction" setting a road from which young people can turn back or - only in the last versions of the textbook - sexual orientation. The context for introducing changes became in the text of the clash between the entities guarding the "old" order and supporters of its change, opposing the normative and obligatory character of heterosexual behaviour.

Keywords: textbooks; homosexuality; moral panic; cultural war 